\title{
Morphology of a pre-collisional, salt-bearing, accretionary complex: The Mediterranean Ridge (Eastern Mediterranean)
}

\author{
C. Huguen ${ }^{1,2, *}$, N. Chamot-Rooke ${ }^{3}$, B. Loubrieu ${ }^{4} \&$ J. Mascle ${ }^{1}$ \\ ${ }^{1}$ UMR 6526 Géosciences-Azur, Observatoire Océanologique de Villefranche-sur-Mer, BP 4806235 , \\ Villefranche-sur-Mer Cedex, France \\ ${ }^{2}$ LEGEM, Université de Perpignan, 52 Avenue de Villeneuve, 66860, Perpignan Cedex, France \\ ${ }^{3}$ Laboratoire de Géologie, CNRS-UMR 8538, Ecole Normale Supérieure, 24 rue Lhomond, 75231, Paris \\ Cedex 05, France \\ ${ }^{4}$ IFREMER, DRO/GM, BP 7029270, Plouzane, France; * Author for correspondence (Tel.: + 33-4-68662049; \\ Fax: +33-4-68661747; E-mail: chuguen@wanadoo.fr)
}

Received 13 December 2004; accepted 10 November 2005

Key words: Eastern Mediterranean, multibeam data, Mediterranean Ridge, subduction

\begin{abstract}
The Eastern Mediterranean Sea is a remnant of a deep Mesozoic oceanic basin, now almost totally consumed as a result of long-term plate convergence between Eurasia and Africa. The present-day surface morphology of the Eastern Mediterranean relates both to the early history of formation of the deep basins and the recent geodynamic interactions between interfering microplates. Among the most conspicuous morphologic features of the basin is an arc-shape, elongated and wide, bathymetric swell bisecting the entire basin from the Ionian to Levantine areas, known as the Mediterranean Ridge. During the last decade this tectono-sedimentary accretionary prism, which results from the Hellenic subduction, has been intensively surveyed by swath mapping, multichannel seismic profiling and deep dives. We present here, and briefly discuss, the main morphological characteristics of this feature as derived from swath bathymetric data that considerably help to better assess the lateral and north-south morphostructural variability of the Mediterranean Ridge. This study reveals that the characteristics and morphostructural variability of the Mediterranean Ridge are related to: (1) a specific incipient collision geodynamic setting south of Crete, where the African and Aegean continental margins are nearly in contact, (2) a unique regional kinematics, controlled by frontal convergence south of Crete (central Mediterranean Ridge) and oblique subduction with opposite sense of shear for the western (Ionian) and eastern (Levantine) domains of the Mediterranean Ridge, that explain the lateral variations of deformation and (3) particularities of its sedimentary cover, which includes massive salt layers within the outer Mediterranean Ridge and local salt deposits within the inner domains, that control the north-south morphostructural variability of the sedimentary wedge.
\end{abstract}

\section{Introduction}

From southwest Peloponnesus to south of Crete and Rhodes, the eastern Mediterranean seafloor is characterized by a large, arc-shaped, sedimentary wedge, more than $1500 \mathrm{~km}$ long and 200-250 km wide, known as the Mediterranean Ridge (Heezen and Ewing, 1963; Emery et al., 1966), which results from the relatively rapid $(>3 \mathrm{~cm} /$ year) subduction of the African plate beneath eastern Europe (Olivet et al., 1982; Le Pichon et al., 1995; Dewey and Sengör, 1979; Kreemer and ChamotRooke, 2004; McClusky et al., 2000; Reillinger et al., 1997) (Figure 1). The Mediterranean Ridge, which consists of a thick pile (up to $12 \mathrm{~km}$ ) of offscrapped and stacked sediments (De Vogdd et al., 1992) deposited since the Mesozoic into the deep Mediterranean oceanic basins and their margins, has long been recognized as a fast (e.g. Kastens, 1991) and rather atypical accretionary prism (Cita and Camerlinghi, 1990; Kastens et al. 1992; Chaumillon and Mascle, 1997), partly because it contains, in its upper sedimentary cover, thick Upper Miocene/Messinian evaporitic sequences (locally up to $2 \mathrm{~km}$ ) (Finetti, 1976; Chaumillon, 1995; Chaumillon et al., 1996; Le Meur, 1997).

The Mediterranean Ridge stretches from the Ionian to the Levantine Basins (Figure 2) as a wide and assymmetric swell, lying at water depths 

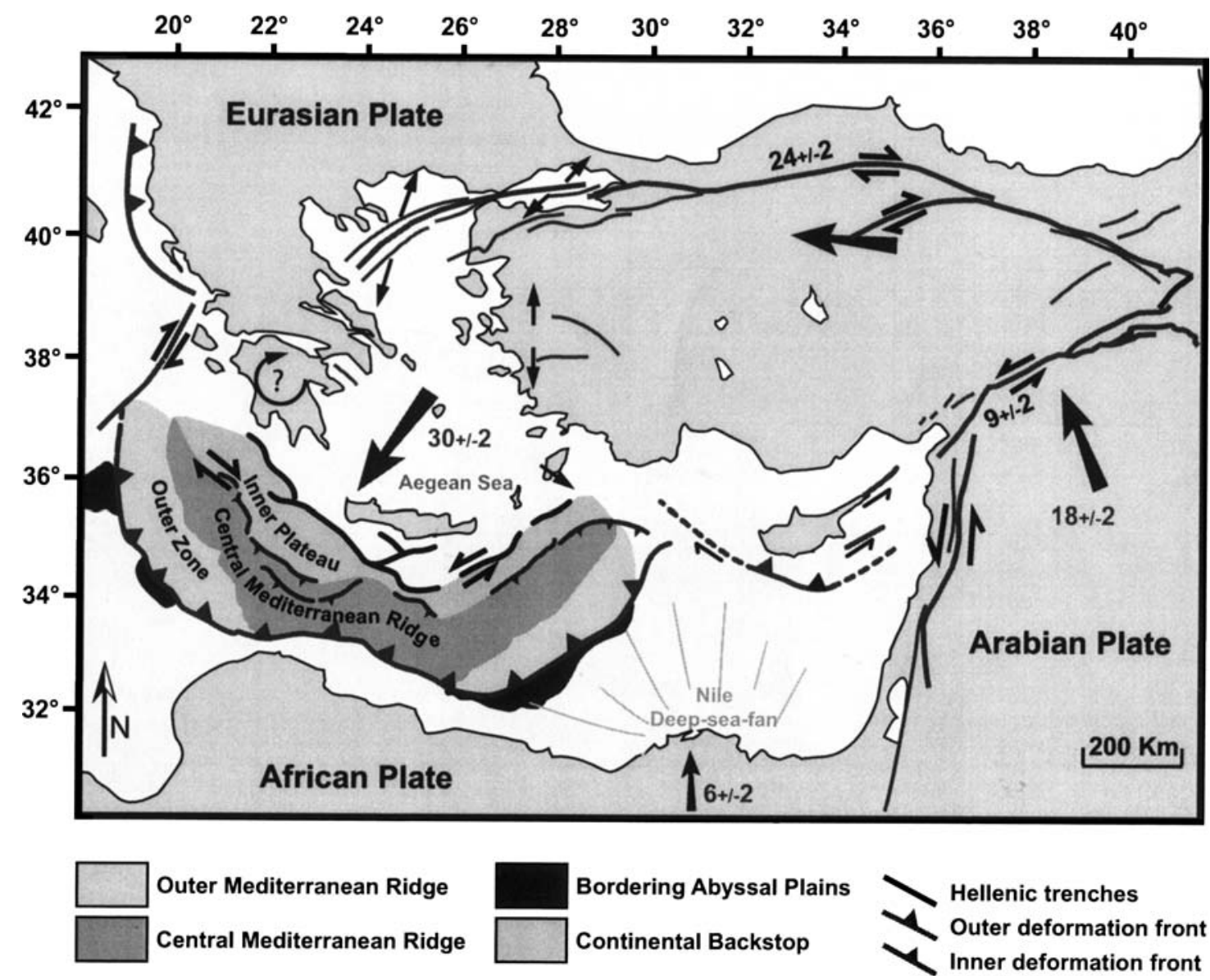

Figure 1. Simplified kinematic and tectonic sketch of the Eastern Mediterranean. The different morphostructural domains identified on the MR are shown, as well as surrounding characteristic seafloor reliefs (modified from Le Pichon et al., 1995; Chaumillon and Mascle, 1997; McClusky et al., 2000).

varying from $1400 \mathrm{~m}$ in its central area to $3000 \mathrm{~m}$, and $2000 \mathrm{~m}$ on average in its western and eastern domains, respectively (Chaumillon, 1995; Le Meur, 1997; Huguen, 2001). To the north, the Mediterranean Ridge is bathymetrically bounded by a series of disconnected and deep troughs (Matapan, Pliny, Strabo Trenches, Rhodes Trough), ranging in depth from 5000 to $3000 \mathrm{~m}$ (Huchon et al., 1982) and surrounding the foot of Peloponnesus, Crete and Rhodes islands continental slopes (Figure 2). To the south, the Mediterranean Ridge faces discontinuous segments of abyssal plains whose water depths range between $4000 \mathrm{~m}$ (Ionian Abyssal Plain) to $3100 \mathrm{~m}$ (Herodotus Abyssal Plain at the base of the Egyptian margin) with only a very narrow, flat-bottomed furrow (water depth averaging $2800 \mathrm{~m}$ ) north of the steep Libyan continental slope (Huguen and Mascle, 2001).
Although the Mediterranean Ridge has been investigated for several decades, both at regional and at local scales, and mostly using reflection (including multichannel seismics) and refraction seismics (Finetti, 1976; Truffert, 1992; De Voogd et al., 1992; Chaumillon, 1995; Chaumillon and Mascle, 1997; IMERSE Working Group, 1997) or geological sampling (Ryan and Hsü, 1973; Cita et al., 1981; Camerlenghi et al., 1992; Robertson et al., 1996), it has always been difficult, based on conventional bathymetry along scattered cross sections and/or point sampling, to precisely image the details of this seabed and to evaluate, at a global scale, the mechanisms that control its intense surface and sub-surface deformations. A better understanding of the morphology at a regional scale, and a better imaging of the Mediterranean Ridge structural patterns, have however 


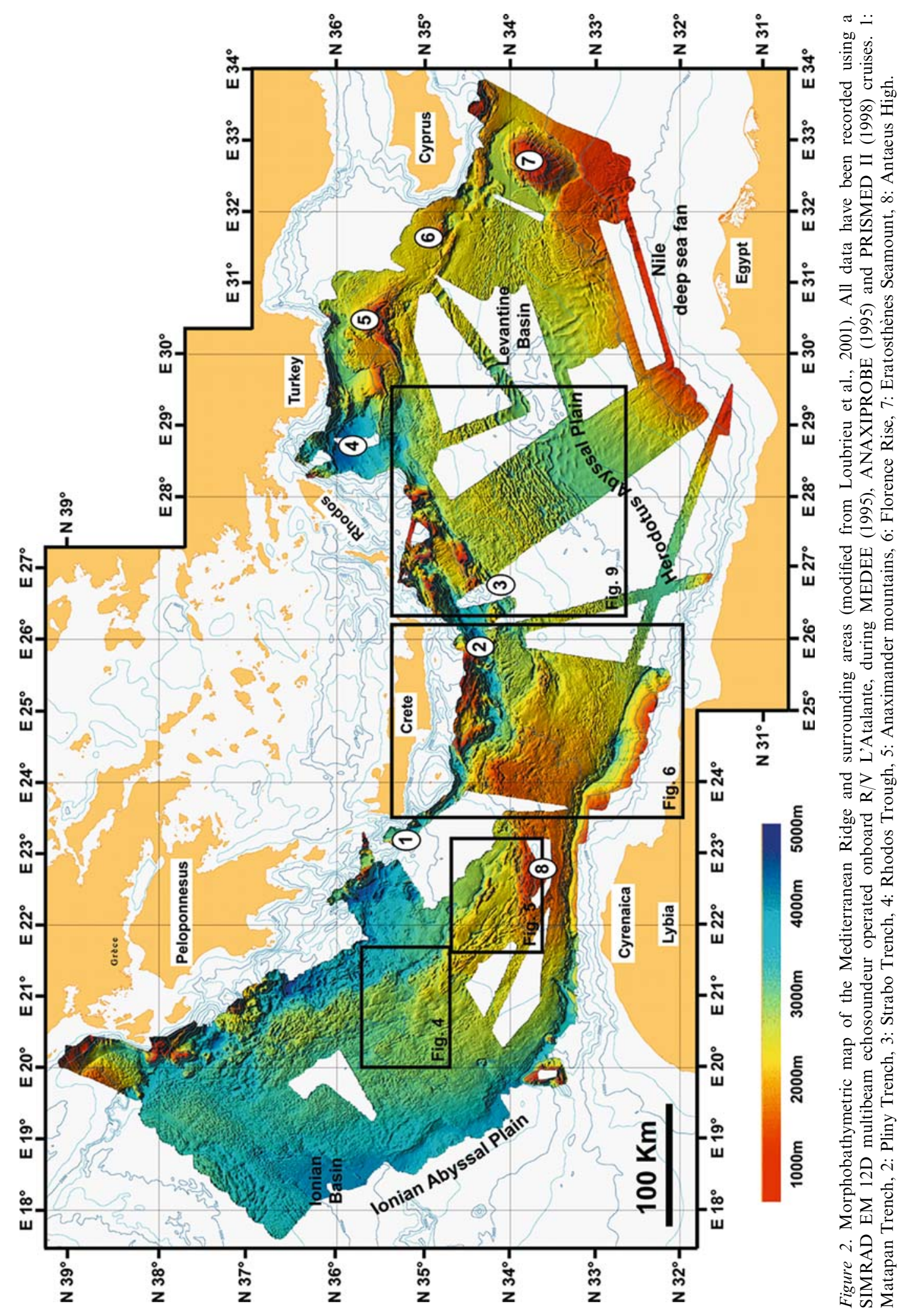




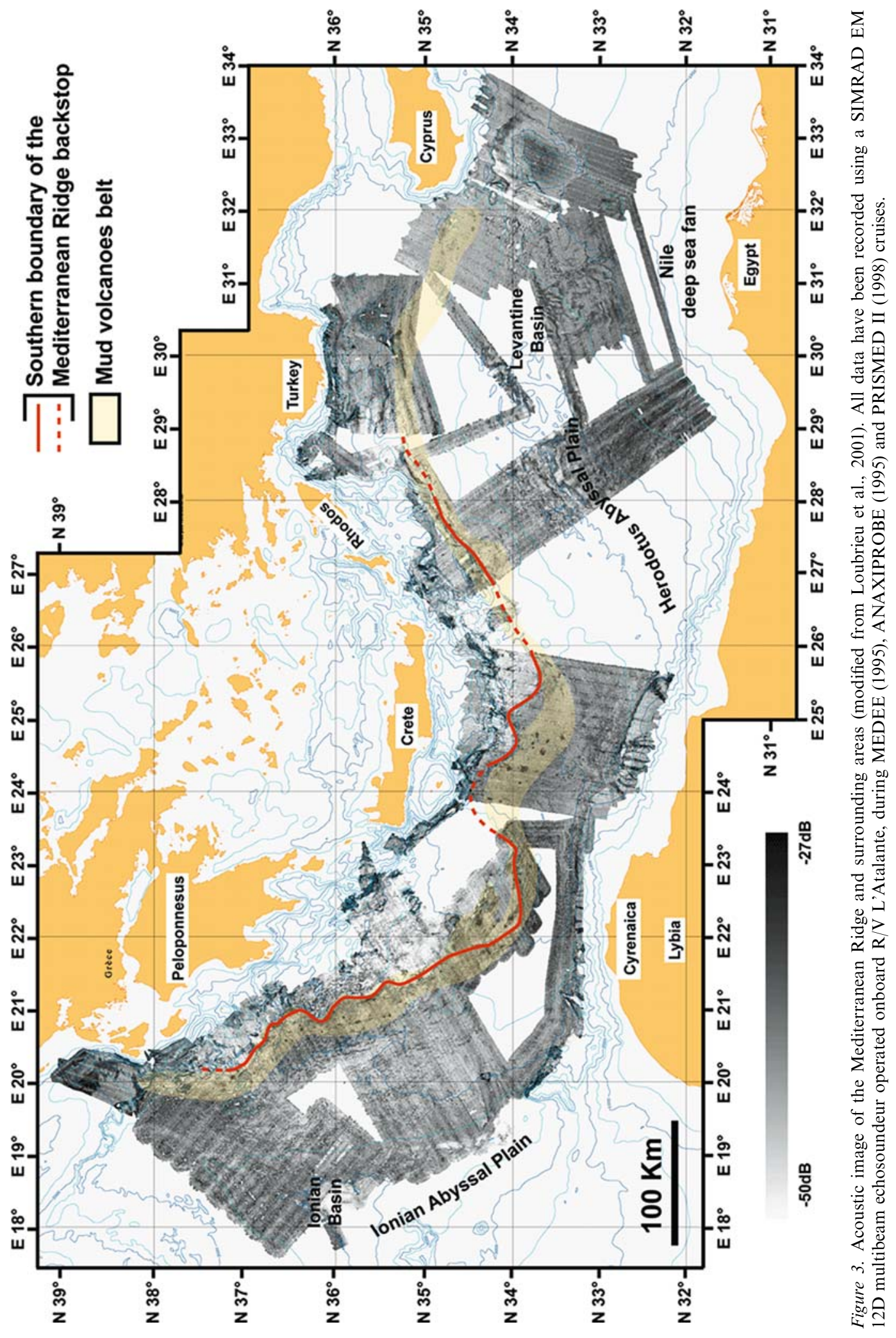


been made easier in the last 10 years by the systematic use of swath mapping (Le Meur, 1997; Huguen, 2001; Nielsen, 2003) and by the acquisition of regional deep penetrating multichannel seismic profiles (De Vogd et al., 1992; Chaumillon, 1995; Chaumillon and Mascle, 1997; IMERSE Working group, 1997).

In this paper, we focus on the morpho-bathymetry of the Mediterranean Ridge, and on the longitudinal/latitudinal surface variations of the ridge, as derived from continuous swath mapping, including bathymetric and backscatter data. This has been made possible mainly thanks to the results of two surveys of the RV L'Atalante, which allowed large areas of the Mediterranean Ridge to be systematically mapped, from its Ionian branch to its Levantine domain facing the Nile margin delta and fan (see Mascle et al., this issue). The MEDEE survey (conducted by the Laboratoire de Géologie ENS-Paris), run in 1995, and the PRISMED II survey (conducted by Géosciences-Azur,
Villefranche/Mer), run in 1998. In addition to these data sets, which cover most of the Mediterranean Ridge (for a total surface of approximately $300,000 \mathrm{~km}^{2}$ ), complementary data from a short survey across the Ionian Basin (HERALIS cruise, run in 1992 by Géosciences-Azur/ Ifremer) and from a one week survey (ANAXIPROBE, in 1995, by Free University Amsterdam), both also onboard the RV L'Atalante, have allowed to complete a detailed mapping of most of the Eastern Mediterranean deep basins. During these cruises, bathymetric and backscatter data have been collected using the same swath system, a Simrad EM12-Dual. This system allowed to record swathes of data about six times the value of the water depth with a $100 / 150 \mathrm{~m}$ resolution. The bathymetric data have been processed using the Ifremer Caraibes software and merged at a $500 \mathrm{~m}$ spacing grid. The backscatter data have been processed using the same software with a pixel size of $62 \mathrm{~m}$. Figures 2 and 3, modified from

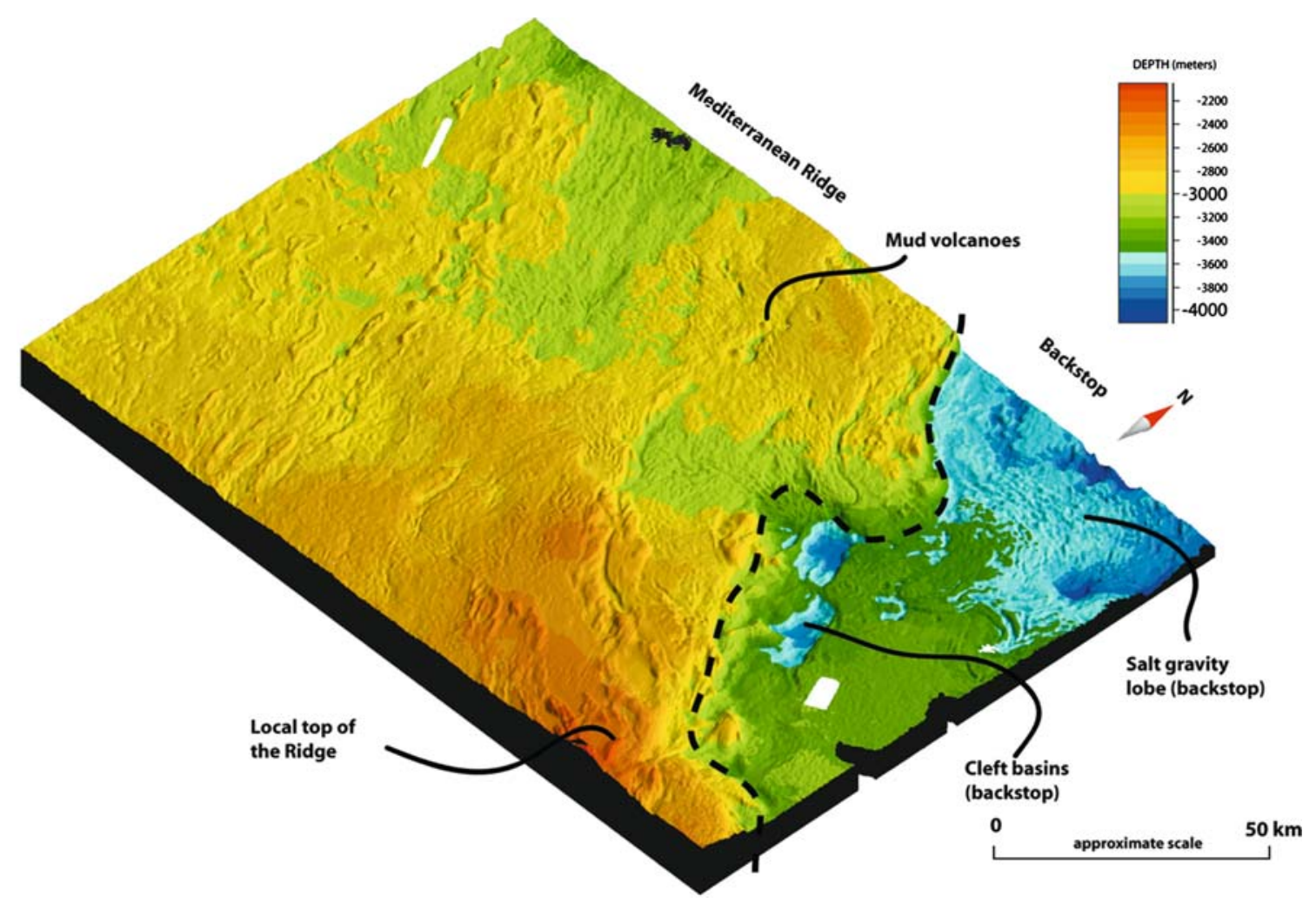

Figure 4. 3D bathymetric view of the Western Mediterranean Ridge branch. The selected region covers shear flower structures at the prism/backstop contact, two deep depressions known as the cleft basins close to this contact, salt gravity lobes and brine depressions over the backstop. 
Loubrieu et al. (2001), result from a compilation of data collected during the four cruises (MEDEE, PRISMED II, HERALIS, ANAXIPROBE).

\section{General morphologic and backscatter characteristics of the Mediterranean Ridge (Figures 2 and 3)}

The deep eastern Mediterranean basin is characterized by three conspicuous morphologic features - besides the Mediterranean Ridge proper - which represents the major morphologic relief. These are (Figure 2): (a) a second arc-shaped feature, the Cyprus arc, which initiates at the level of a series of reliefs lying south of Turkey (Anaximander Mountains) and comprises the Florence Rise, the Cyprus margin, to finally stretch towards the Levantine coasts off Syria; (b) a massive, flat-topped, block (Eratosthenes Seamount), which lies between Cyprus and (c) a wide sedimentary construction covering most of the Egyptian margin, the Nile deep sea fan. The eastern Mediterranean bordering continental margins are either intensively block-faulted (southern Aegean margin), or made of wide and sedimented (offshore Egypt), or quite narrow and steep (off Libya) passive margin segments.

The Mediterranean Ridge shows significant longitudinal variations both in depth and width. Its summit, just north of Cyrenaica (Antaeus High, Figure 2), reaches water depth of less than $1250 \mathrm{~m}$, while its Ionian and Levantine branches extend into water depths of approximately respectively 3200 and $2200 \mathrm{~m}$; both domains gradually deepen towards west and east, respectively. The Mediterranean Ridge shows also a quite variable width. It reaches its maximum width, about $200 \mathrm{~km}$, facing the deep Ionian Abyssal Plain. Between central Crete and Libya, the ridge appears much narrower, with an average width of only $130 \mathrm{~km}$. The transition between the Ionian and Central domains, is marked by a sudden morphologic inflexion: while the Mediterranean Ridge is NW-SE trending in the Ionian Sea, it shows - in coincidence with its shallowest area - a sharp change in trend. From there, and towards the east, the Mediterranean Ridge general trend is roughly WSW-ENE.
The Mediterranean Ridge also displays important north-south variations, which can be recognized all along the feature from its western extremity to its eastern end (still poorly defined). Within the western Mediterranean Ridge, Truffert (1992) identified, on the base of the deformational pattern, three different morphostructural provinces: an outer folded front, an almost flat central province, and a northern area in tectonic backthrust contact with a flat inner region extending just south of the deep troughs (Matapan Trench) that run at the base of the Aegean continental slope. Comparable morphostructural domains, showing local variations, have been recognized within the central and Levantine Mediterranean Ridge branches (Chaumillon, 1995; Huguen, 2001).

On backscatter images (Figure 3) the different morphostructural domains, as defined on bathymetric grounds, are easy to detect on the basis of different levels of reflectivity. We notice two points of particular interest:

- A relatively strong backscatter contrast exists between the Mediterranean Ridge itself (which shows local variations depending chiefly of the wavelength and type of surface deformations) and the morphologically less disturbed and deeper domain bordering the Mediterranean Ridge to the north. This contrast has been used as a marker to delineate the southern extension of the Mediterranean Ridge backstop, interpreted as the potential prolongation of alpine nappes which constitute most of the south Aegean margin basement (Lallemand et al., 1994).

- High reflectivity and subcircular patches (in black on Figure 3) are seen delineating a discontinuous but clear belt (as suggested by Limonov et al., 1996) located more or less at the boundary between the Mediterranean Ridge northern province and the surrounding deeper backstop area. Based on sampling and/or direct in situ observations several of these features have been interpreted as mud volcanoes through which massive mud flows, fluids and brines are emitted on the sea floor (Cita and Camerlenghi, 1990; Cita et al., 1995; Galindo-Zaldivar et al., 1996; Hieke et al., 1996; Volgin and Woodside, 1996; Fusi and Kenyon, 1996; Ivanov et al., 1996; Cronin et al., 1997; Emeis et al., 1996; Robertson 

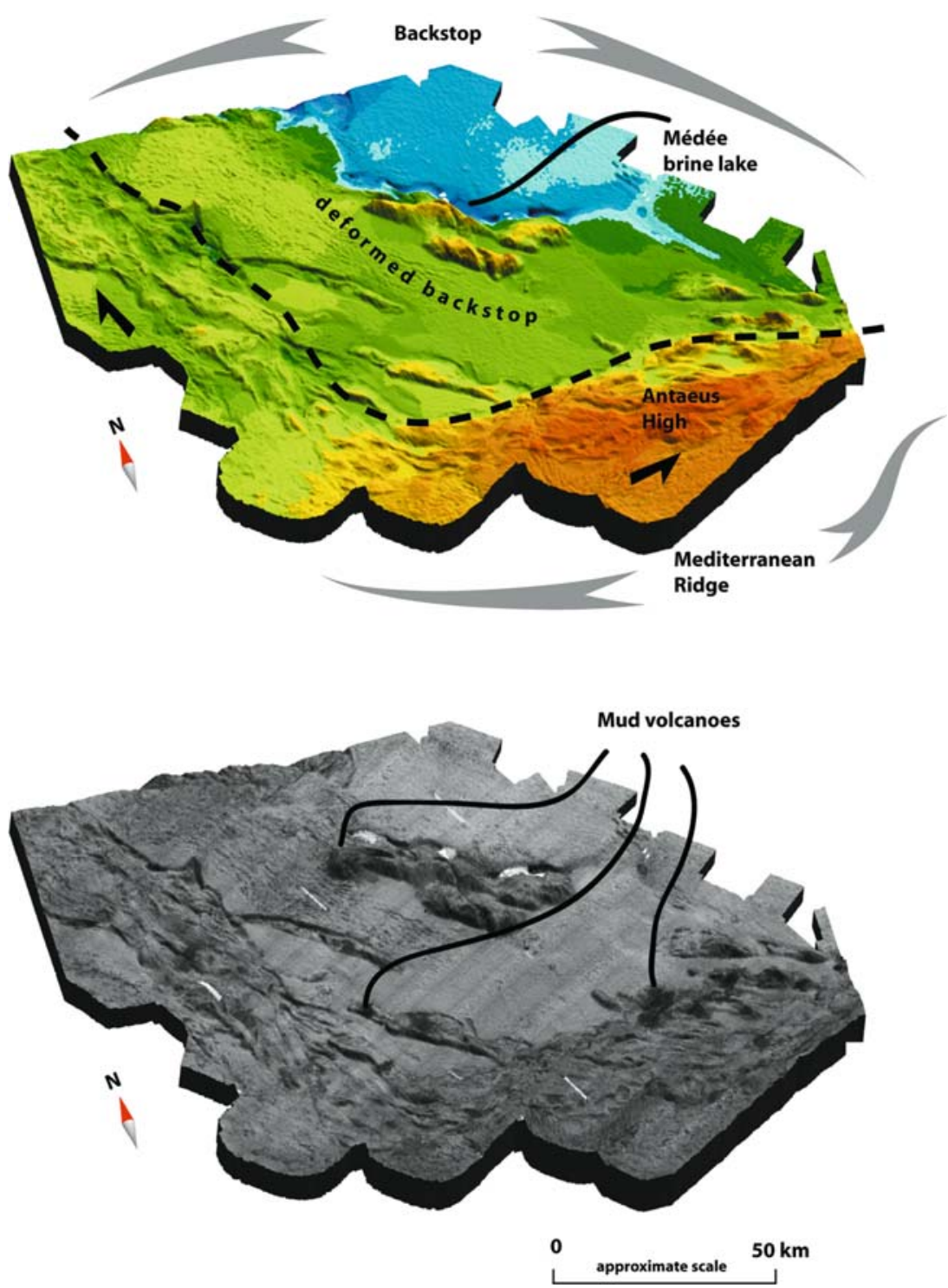

Figure 5. 3D bathymetric view (top) and same area with overlapped backscatter texture (bottom) in the region of the top Mediterranean Ridge (Antaeus High).

et al., 1996; Kopf et al., 1998; Huguen et al., 2004, 2005).

\section{The Western Mediterranean Ridge: From Antaeus High to Calabrian wedge}

The Western Mediterranean Ridge (Figure 4) extends from the very top of the Mediterranean Ridge offshore Libya - i.e. Antaeus High (Figure 2) - to the transition with the Calabrian prism offshore the Ionian Islands (Le Pichon et al.,
1995; Reston et al., 2002a; Kreemer and Chamot Rooke, 2004). The morphology of the western Mediterranean Ridge is mostly controlled by its relationships with the surroundings structural elements: the African margin and related reliefs carried by the plate and transported into the prism (von Huene et al., 1997); the Mediterranean Ridge Hellenic backstop (Figures 3 and 4), acting as a mechanical "buttress" of complex shape (ChamotRooke et al., 1993; Truffert et al., 1993; Jones et al., 2002; Le Pichon et al., 2002; Costa et al., 2005) and the Calabrian wedge to the northwest 


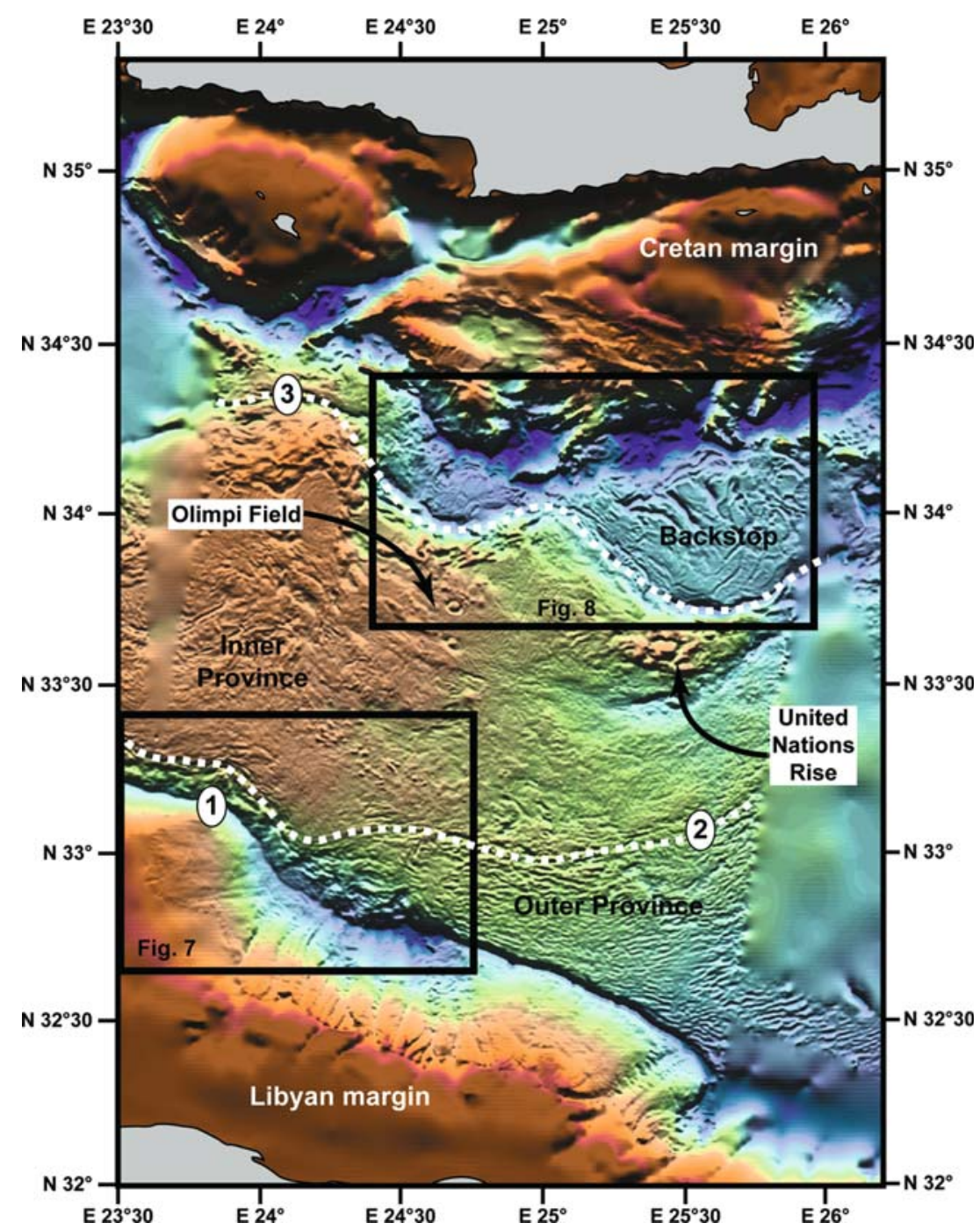

Figure 6. Shaded bathymetry of the Central Mediterranean Ridge (Huguen, 2001). Data from PRISMED II cruise (1998). 1: Outer deformation front (Imbricate thrusts), 2: Contact between the outer and axial provinces (thrust belt), 3: Inner deformation front (Backthrust area).

(Tortorici et al., 1995). The distribution of Messinian evaporites is quite heterogeneous (Chaumillon et al., 1996; Reston et al., 2002b), as a result of the complex configuration of the basins at the time of deposition.

The African margin and backstop edge are in close contact in the Antaeus region, so that the wedge has little space to grow there. The ridge offshore Cyrenaica is narrow and tightly folded (Figure 2). Folds around the Antaeus High are arranged en-échelon, indicating sinistral shear at the contact with the backstop. The steep African margin is actually already engaged below the ridge, and as a result outward growth of the wedge has recently stopped: the ongoing convergence is accommodated along out-of-sequence thrusts developed along the east-west oriented portion of the wedge front between longitudes $22^{\circ} \mathrm{E}$ and $23^{\circ} 30^{\prime} \mathrm{E}$ (Figure 2). Proximity of the African margin has also resulted in a number of asperities that form part of the African plate, deforming previously accreted sediments as they impact the prism. The largest asperities have created large scars that can be followed several tens of $\mathrm{km}$ from the wedge front. The "Bannock Basin", interpreted as a major depression, has been recognized based on seismic as the product of subduction of a major seamount probably 


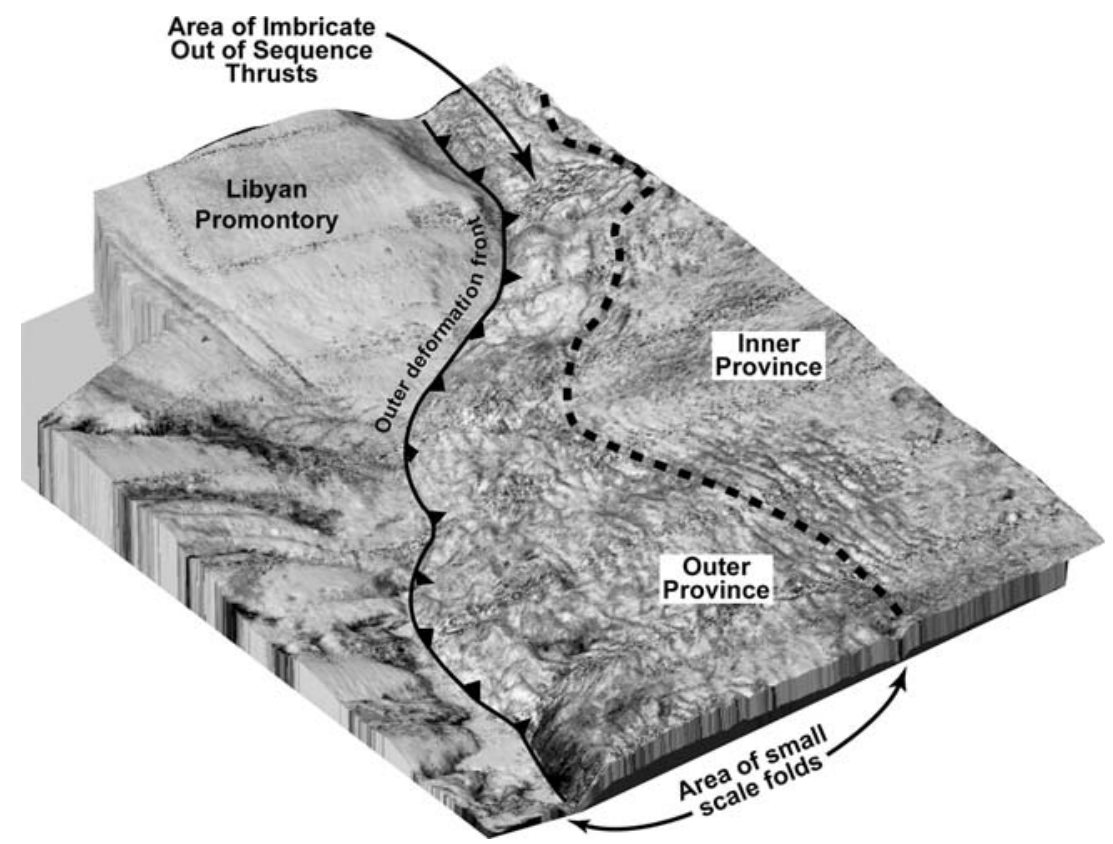

Figure 7. 3D bathymetric view and overlapped backscatter data, of the Cretan continental backstop and northern Mediterranean Ridge (see location on Figure 6).

reaching more than $50 \mathrm{~km}$ width at its base (Von Huene et al., 1997). Smaller highs indent the toe of the wedge at all scales, including ridges, seamounts, and tilted blocks of the African margin.

The boundary between the western Mediterranean Ridge and its backstop (Figures 3-5) is now well defined based on the reflectivity contrast between highly reflective prism and poorly reflective buttress (see earlier general discussion). This backstop not only extends far south of the Hellenic Trenches, but its southern edge also has a complex "W" shape (Le Pichon et al., 1995, 2002; Costa et al., 2005). The morphologic contact of the ridge units with the backstop is particularly sharp along the main portion of the western Mediterranean Ridge, perhaps with the exception of its northwestern termination. These ridge units are systematically thrusted over the backstop, with clear evidence for dextral shearing (strike-slip faults punctuated with mud volcanoes, small pull-apart basins in releasing bends and folded units in restraining bends). Mud volcanoes of all size punctuate the entire region (Figure 3), with $95 \%$ of them located at proximity of the prism/ backstop contact (Chamot-Rooke et al., in press). The new bathymetric and backscatter maps (Figures 4 and 5) reveal the complex internal structure of the backstop. Part of it has been covered by
Messinian units, which are now systematically gliding towards the remnant Hellenic Trenches, resulting into an extraordinary salt tectonics including sub-circular salt lobes (e.g. $35^{\circ} \mathrm{N}-22^{\circ}$ E) with tight gravity folding and "rafts" of PlioQuaternary.

The northwestern termination of the western Mediterranean Ridge (Figs. 2 and 3) shows interaction with the toe of the Calabrian prism and the Kephalonia Transform Fault. A narrow corridor of imbricated NE-SW oriented ridges and troughs prolongates at sea as the right lateral Kephalonia Fault. This corridor also coincides with the transition to the Calabrian prism. Surface structures identified in this transitional domain relate to the contrasting growing rates of the two wedges (Le Pichon et al., 1995; D'Agostino and Selvaggi, 2004). The western Mediterranean Ridge is growing rapidly with the progressive incorporation of African margin sediments. The Calabrian prism, by contrast, is probably growing at a very slow rate. The result is that the region of intersection of the two wedges is controled by the rapid southwest migration through time of the Mediterranean Ridge front.

In addition to the geological and structural elements, surface deformation of the western Mediterranean Ridge is also strongly controled 


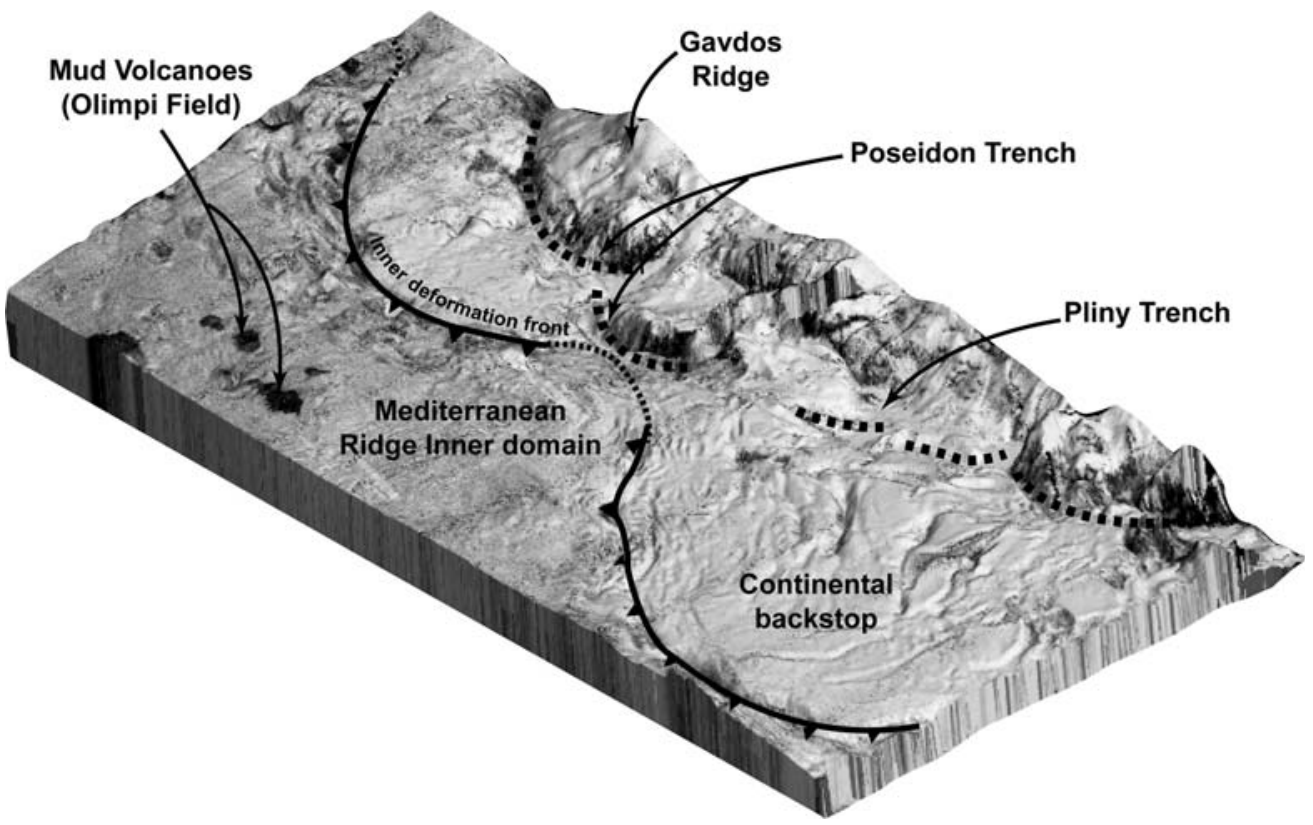

Figure 8. 3D bathymetric view, and overlapped backscatter data, of the Libyan continental margin and its contact with the Mediterranean Ridge outer domain (see location on Figure 6).

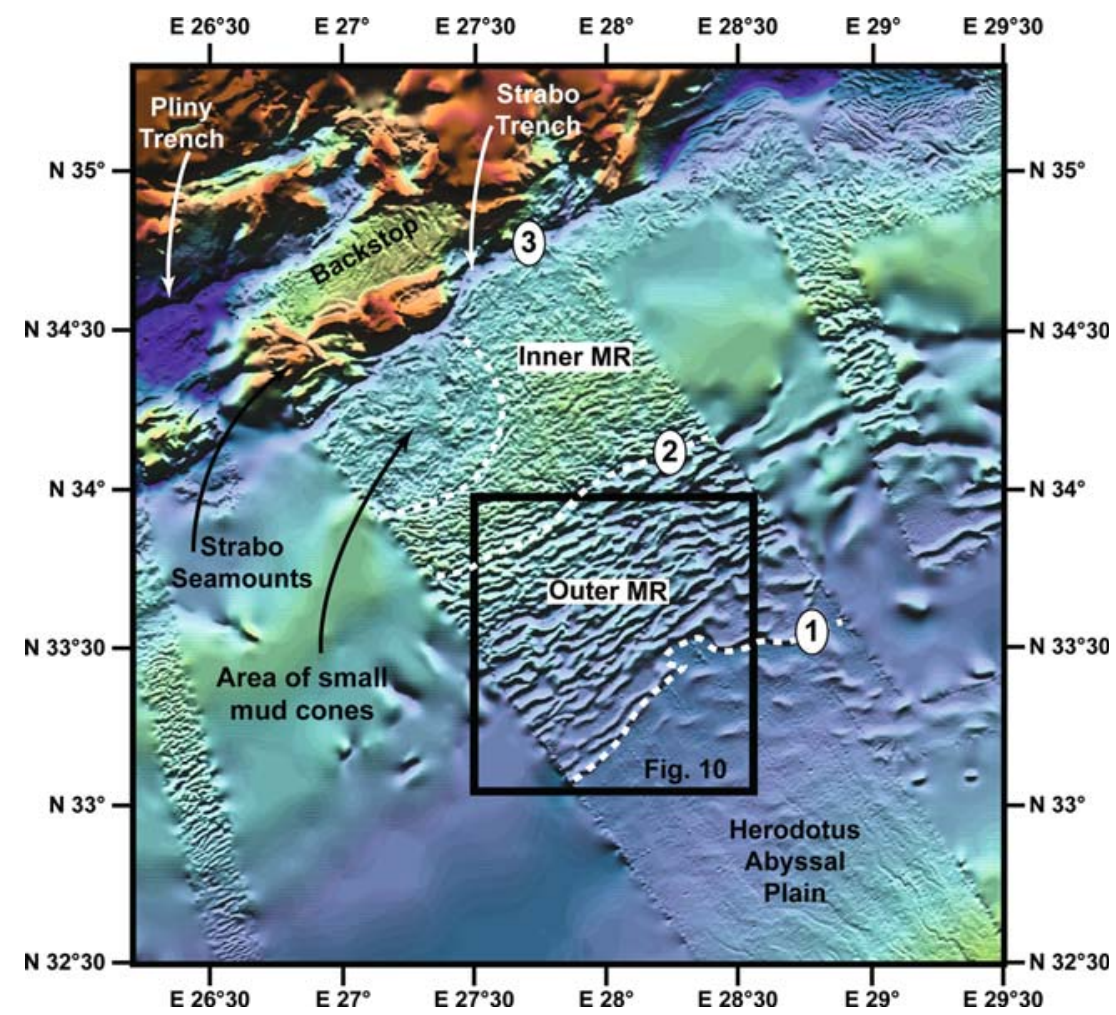

Figure 9. Shaded bathymetry of the Eastern Mediterranean Ridge (Huguen, 2001). Data from PRISMED II cruise (1998). 1: Outer déformation front, 2: Contact between the outer and axial provinces, 3: Inner deformation front (Backthrust area). 


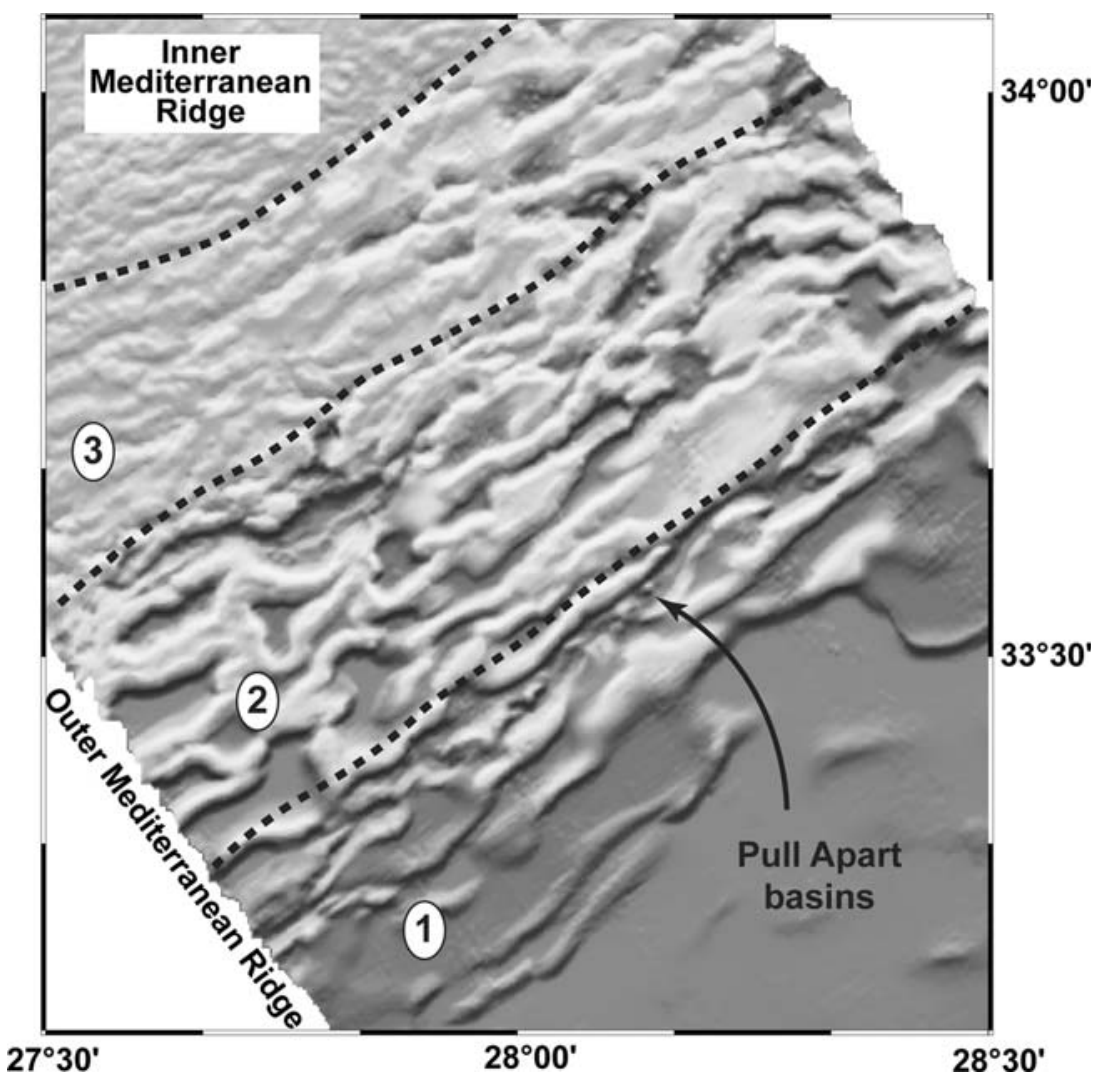

Figure 10. Bathymetry of the Eastern Mediterranean folded outer domain and its contact with the Herodotus Abyssal plain (See location on Figure 9). 1-3: Successive fold belts possibly disconnected by strike-slip lineaments (1: Southern asymmetric folds, 2: Northern symmetric folds, 3: Transition zone) (Modified from Huguen et al., 2001).

by the distribution of Messinian evaporites. The Messinian wedge (i.e. the portion of the wedge that incorporates Messinian evaporites originally deposited in the subduction trough) does not exceed $80 \mathrm{~km}$ in width. The remaining portion of the wedge is build by Miocene sediments (Cita et al., 1981) accreted during the early stages of formation of the Mediterranean Ridge. Quite surprisingly, Messinian evaporites are also present close to the apex of the western Mediterranean Ridge. They seem to have been deposited in deep troughs close or at the backstop contact, thus suggesting important post-depositional tectonic uplift.

\section{The Central Mediterranean Ridge: A pre-collision stage}

From E23 30 to E26 lies an area of the Mediterranean Ridge where the now well-known Olimpi and United Nations mud volcano fields (Figure 6) have previously been detected (Cita et al., 1981) and intensively surveyed during PRISMED 2 and later on during MEDINAUT and NAUTINIL surveys (Huguen et al., 2004, 2005). On bathymetry (Figure 6), as well as on acoustic imagery, this segment of the Mediterranean Ridge, or central Mediterranean Ridge, (Chaumillon, 1995; Mascle et al., 1999; Huguen, 2001) displays the same three different morphostructural provinces recognized at the scale of the entire ridge, i.e. an outer province almost directly in contact with the steep Libyan continental slope and an inner, quite flat, province where most of the mud volcanoes fields are detected. Northwards, the Mediterranean Ridge is bounded by a line of arc-shaped reliefs overhanging a deeper basin that is itself disconnected from the massive block-faulted reliefs, which constitute the Cretan continental slope (Chaumillon et al., 1996).

Within the outermost area, there is a transition in deformational styles from a narrow and steep frontal zone, facing the Libyan promontory 
(Cyrenaica), to an eastward progressively widening series of folds (Chaumillon and Mascle, 1997; Huguen and Mascle, 2001) (Figures 6 and 7). The sharp contact with the African margin is characterized by several morphologic steps, which are bathymetric expressions of imbricate out of sequence thrusts (Huguen, 2001). On seismic data no evidence of thick Messinian evaporites is detected in this part of the Mediterranean Ridge deformation front, which directly overthrusts the African continental slope (Chaumillon and Mascle, 1997); Eastward the Mediterranean Ridge toe prolongates through small, short wavelength, ENE-trending, folds progressively increasing in size and widening (Figures 6 and 7). This fold belt is made of salt-rooted anticline-synclines developing above a décollement level, which correlates with the base of Messinian evaporites (Chaumillon and Mascle, 1997; Huguen, 2001). Interestingly, the backscatter data illustrate that this folded belt is cut by a dense set of conjugate faults, probably strike-slip faults, either triggered by southwards progressive spreading of the salt-rich and ductile superficial cover and/or by a lateral response to indenting of the Mediterranean Ridge outer front against the rigid African margin (Huguen and Mascle, 2001). Within the axial domain no evaporites layers of significant extend have been found (Kopf et al., 2003), resulting in a different morphostructural pattern, mainly characterized by small scale folding (Mascle et al., 1999; Huguen, 2001) and fields of mud volcanoes (Figures 3 and 6). The contact between the outer and axial domains is well defined by a thrust belt (Huguen, 2001). We believe this belt corresponds to a structural boundary between a pre-Messinian accreted wedge to the north and a post-Messinian accreted domain to the south, built over a décollement level at the base, or within, the Messinian evaporites (Chaumillon and Mascle, 1997). This hypothesis is attested to by a ductile compressive deformation style chiefly observed within the outer domain, and the presence of mud volcanoes extruding Aptian shales within the northern domain (Cita et al., 1995; Huguen et al., 2001). Finally the Mediterranean Ridge inner front is marked as a series of arcuate reliefs backtrusting over a deep basinal area where evidence of salt triggered gravity deformation is seen (Figure 8). The sedimentary cover of this last area is in fact progressively gliding northward and filling the series of deep troughs that constitute the Pliny Trench at the foot of the Cretan continental slope.

\section{The Eastern Mediterranean Ridge: Oblique subduction}

The eastern (or Levantine) Mediterranean Ridge branch (Figures 3 and 9) can only be traced with confidence up to East $29^{\circ} 30^{\prime}$, region where the data are still too scarce to define its transition towards the Florence Rise-Cyprus arc system. Between the south-eastern Cretan margin and the Herodotus Abyssal Plain (Figure 9), several domains characterized by different morphostructural patterns can be identified (Huguen, 2001; Huguen et al., 2001; Chaumillon and Mascle, 1997; Chaumillon, 1995). The Cretan margin itself appears segmented by the Pliny and Strabo Trenches, composed by a set of disconnected "en echelon" distributed deep troughs with a general NE-SW trend. Between these two trenches, the backstop area is composed of: a plateau-like area, slightly sloping northwards, and characterized by large lobe-like features, interpreted as gravity induced deformation (Mascle et al., 1999), and the Strabo Seamounts, a series of massive bathymetric highs trending in a general $\mathrm{N} 60^{\circ}$ direction, rifted from the Cretan margin (Leité and Mascle, 1982). Backthrusting over these reliefs, the Mediterranean Ridge inner domain, only weakly folded, appears partly cut by lineaments of probable strike-slip origin and characterized by numerous small dome-like mud expulsion centers and possibly by wide areas of mud flows (Huguen et al., 2001). South of this area, an outer domain is characterized by a system of large-scale folds (Figure 10), progressively increasing in width to the south, and possibly disconnected into three distinct belts by strike-slip lineaments (Huguen et al., 2001).

As for the central and western Mediterranean Ridge provinces, such morphologic contrast is believed to reflect a two stages tectonosedimentary accretion process, a pre-Messinian one in the inner part of the feature, and a postMessinian one where thick evaporites are directly involved in the record of a transpessionnal regime as expected from regional kinematics (Chaumillon and Mascle, 1997). However, the 
identification of successive folded belts, disconnected by sigmoid basins, within this part of the outer domain may result from potential interactions of distinct, and non-exclusive, processes. On one hand, a general transfer of the Mediterranean Ridge accreting sediments to the northeast, in response to a left lateral strike-slip motion in an oblique subduction setting, on the other hand, a component of gravity-triggered southward spreading of a salt-rich sedimentary cover cannot be excluded (Huguen et al., 2001).

\section{Conclusion}

When compared to other accretionary prisms, the Mediterranean Ridge shows many unique morphostructural characteristics, both along its trend and transversally. These variations are believed to be controled by several main parameters: a specific geodynamic setting (incipient collision), a unique regional kinematics (frontal convergence south of Crete and oblique subduction with opposite sense of shear for the Ionian and Levantine domains), and finally a complex distribution, within parts of its cover, of thick ductile sedimentary layers (i.e. Messinian evaporites).

The narrow Central Mediterranean Ridge, south of Crete, which appears to be the most differentiated region, may reflect through its morphology a complex underlying crustal arrangement. The two continental margins, African and Aegean, are nearly in contact in that area (Huguen, 2001). The western and eastern Mediterranean Ridge branches, still facing free borders (Ionian and Levantine oceanic basins), are still ruled and deformed by more steady-state subduction processes, although strongly controled by oblique tectonics (Kremer and Chamot Rooke, 2004; Costa et al., 2005). Along the western branch, shearing is presently localized at the geological contact between the ridge and its backstop, thus interpreted as a major dextral, compressive flower structure, as well as a preferential site for massive mud eruption (Chamot-Rooke et al., in press). Along the eastern branch, shearing is also mainly restricted to the boundary between the Cretan margin and the backstop area (Pliny Trench) and the contact between the Strabo Mountains and the Mediterranean Ridge Inner domain (Strabo
Trench). Both trenches are composed of successive wide and partly sedimented basins, en echelon arranged, and clearly representative of left lateral strike-slip movement. Strike slip movements are also inferred within the Mediterranean Ridge outer domain between the successive fault belts and might be explained by a partitioning of the shearing deformation (Huguen et al., 2001).

The presence of Messinian salt layers at the toe of the wedge (Huguen and Mascle, 2001), but also within the prism and over the continental backstop, clearly controls the small-scale surface deformation (Chaumillon and Mascle, 1997). Within the outer Mediterranean Ridge domain, these ductile layers result in significant folding. Folds are tight where evaporites are thin, in particular between Crete and Libya where little space is available for the wedge to grow, and they progressively widen towards the Levantine and Ionian branches of the Mediterranean Ridge due to both thickening of the evaporitic layers and persistence of "open borders" south of the Mediterranean Ridge toe. The flat and deeper backstop area shows well expressed northward gliding deformations over the entire studied area, interpreted as the result of ductile salt tectonics related to the presence of evaporite layers, deposited within a pre-existing fore-arc basin setting and acting as a passive decollement level (Chaumillon, 1995; Huguen, 2001; Huguen et al., 2001).

\section{Acknowledgements}

This study is based on a data set mainly recorded during the MEDEE (1995) and PRISMED II (1998) surveys. We thank the officers, technical staff, and crew, of Ifremer-Genavir R.V. L' Atalante, as well as the scientific parties of both cruises. This is contribution number 746 of Geosciences-Azur UMR CNRS No. 6526.

\section{References}

Camerlenghi, A., Cita, M.B., Hieke, W. and Ricchiuto, T., 1992, Geological evidence for mud diapirism on the Mediterranean Ridge accretionary complex, Earth Planet. Sci. Letts 109, 493-504.

Chamot-Rooke, N., Foucher, J.P., Lallemant, S., Truffert, C., Alexandry, M., Monti, S. and Pavlakis P., 1993, Structure of the Western Mediterranean Ridge from a multibeam 
bathymetric survey (HERALIS Cruise, July 1992). Seventh meeting of the European Union of Geosciences, abstract supplement. Terra Abstr. 5(1), 277.

Chamot-Rooke, N., Rabaute, A. and Kreemer, C., 2005, Western Mediterranean Ridge mud belt correlates with active shear strain at the prism-backstop geological contact, Geology, 33(11), 861-864.

Chaumillon, E., 1995, Structure de la Ride Méditerranéenne: apports de la sismique multitrace. Thèse de 3ème cycle de l'Université Pierre et Marie Curie, Paris VI.

Chaumillon, E. and Mascle, J., 1997, From foreland to forearc domains: New multichannel seismic reflection survey of the Mediterranean Ridge accretionary complex (Eastern Mediterranean), Marine Geol. 138, 237-259.

Chaumillon, E., Mascle, J. and Hoffmann, J., 1996, Deformation of the western Mediterranean Ridge: importance of Messinian evaporitic formations, Tectonophysics 263, 163-190.

Cita, M.B. and Camerlenghi, A., 1990, The Mediterranean Ridge as an accretionary prism in collisional context, Memorie della Società Geologica Italiana 45, 463-480.

Cita, M.B., Ryan, W.B.F. and Paggi, L., 1981, Prometheus mud breccia: an example of shale diapirism in the Western Mediterrranean Ridge, Annales géologiques des pays Helléniques 30, 543-569.

Cita, M.B., Woodside, J.M., Ivanov, M.K., Kidd, R.B., Limonov, A.F., Shipboard Scientific Party TTR3-Leg2, 1995, Fluid venting from a mud volcano in the Mediterranean Ridge Diapiric belt. Terra Nova 7, 453-458.

Costa, E., Camerlenghi, A., Polonia, A., Cooper, C., Fabretti, P., Mosconi, A., Murelli, P., Romanelli, M., Sormani, L. and Wardell, N., 2005, Modeling deformation and salt tectonics in the eastern Mediterranean Ridge accretionary wedge, Geol. Soc. Am. Bull. 116, 880-894.

Cronin, B.T., Ivanov, M.K., Limonov, A.F., Egorov, A., Akhmanov, G.G., Akhmetjanov, A.M., Kozlova, E. and TTR-5 shipboard scientific party, 1997, New discoveries of mud volcanoes on the Eastern Mediterranean Ridge, J. Geol. Soc. London 154, 173-182.

D'Agostino, N. and Selvaggi, G., 2004, Crustal motion along the Eurasia-Nubia plate boundary in the Calabrian Arc and Sicily and active extension in the Messina Straits from GPS measurements, J. Geophys. Res. 109, No. B11, B11402.

De Voogd, B., Truffert, C., Chamot-Rooke, N., Huchon, P., Lallemant, S. and Le Pichon, X., 1992, Two-ship deep seismic sounding in the basins of the Eastern Mediterranean Sea (Pasiphae cruise), Geophys. J. Intel 109, 536-552.

Dewey, J.F. and Sengör, C.A.M., 1979, Aegean and surrounding regions: complex multiplate and continuum tectonics in a convergent zone, Geol. Soc. Am. Bull. 90, 84-92.

Emeis, K.C. and Robertson, A.H. (ed.), 1996, Proceedings of the Ocean Drilling Program, Initial Reports, Mediterranean I, College Station, TX (Ocean Drilling Program) 160.

Emery, K.O., Heezen, B. and Allan, T.D., 1966, Bathymetry of the Eastern Mediterranean sea, Deep Sea Res. 13, 173-192.

Finetti, I., 1976, Mediterranean Ridge: a young submerged chain associated with the Hellenic Arc, Boll. Geofisica Teoria Appl. 19, 31-65.

Fusi, N. and Kenyon, N.H., 1996, Distribution of mud diapirism and other geological structures from long-range sidescan sonar (GLORIA) data, in the Eastern Mediterranean Sea, Marine Geol. 132, 21-38.
Galindo-Zaldivar, J., Nieto, L. and Woodside, J., 1996, Structural features of mud volcanoes and the fold system of the Mediterranean Ridge, south of Crete, Marine Geol. 132, 95-112.

Heezen, B.C. and Ewing, M., 1963, The Mid Oceanic Ridge. in Hill, M.N. (ed.), The Seas, vol. 3, Interscience, New York, pp. $388-410$.

Hieke, W., Werner, F. and Schenke, H.W., 1996, Geomorphological study of an area with mud diapirs south of Crete (Mediterranean Ridge), Marine Geol. 132, 63-93.

Huchon, P., Lyberis, N., Angelier, J., Le Pichon, X. and Renard, V., 1982, Tectonics of the Hellenic Trench: a synthesis of Sea-Beam and submersible observations, Tectonophysics 86, 69-112.

Huguen, C., 2001, Déformation récente à actuelle et argilocinèse associèe au sein de la Ride Méditerranéenne (Méditerranée Orientale). Thèse de Doctorat, Université Paris VI.

Huguen, C. and Mascle, J., 2001, La Marge Lybienne, entre $23^{\circ} 30$ et $25^{\circ} 30$ de Longitude Est, Comptes Rendus à l'Académie des Sci Paris 332, 553-560.

Huguen, C., Mascle, J., Chaumillon, E., Woodside, J.M., Benkhelil, J., Kopf, A. and Volkonskaia, A., 2001, Deformational styles of the Eastern Mediterranean ridge and surroundings, from combined swath-mapping and seismic reflection profiling, Tectonophysics 343, 21-47.

Huguen, C., Mascle, J., Chaumillon, E., Griboulard, R., Kopf, A. and Woodside, J.M., 2004, Structural setting and Tectonic control on Mud volcanoes: Evidences from the Central and Eastern Mediterranean Ridge from geophysical data, Marine Geol. 209, 245-263.

Huguen, C., Mascle, J., Woodside, J.M. and Zitter, T., 2005, An in situ and near-bottom study of Mud Volcanoes in the Eastern Mediterranean Pre-Collisionnal Setting, Deep Sea Res. I 52, 1911-1931.

IMERSE Working group, 1997, Mediterranean Ridge structure: Results from International Mediterranean Ridge Seismic Experiment, Eos Trans. Am. Geophys. Union 78, 155.

Ivanov, M.K., Limonov, A.F., Cronin, B.T. (ed.), 1996, Mud volcanism and fluid venting in the eastern part of the Mediterranean Ridge, Initial results of the geological and geophysical investigations during the fifth UNESCO-ESF "Training-Through-Research" Cruise of RV Professor Logachev (July-september 1995). Unesco Reports in Marine Science 68

Jones, K.A., Warner, M., Le Meur, D., Pascal, G., Tay, P.L. and the IMERSE working group, 2002, Wide angle images of the Mediterranean Ridge backstop structure. Marine Geol. 186, 145-166.

Kastens, K.A., 1991, Rate of outward growth of the Mediterranean Ridge accretionary complex, Tectonophysics 199, $25-50$.

Kastens, K.A., Breen, N.A. and Cita, M.B., 1992, Progressive deformation of an evaporite-bearing accretionary complex: SeaMARC I, SeaBeam and Piston-core observations from the Mediterranean Ridge, Marine Geophys. Res. 14, 249298.

Kopf, A., Mascle, M. and Klaeschen, D., 2003, The Mediterranean Ridge: A mass balance across the fastest growing accretionary complex on Earth, J. Geophys. Res. 108, 2372-2403.

Kopf, A., Robertson, A.H.F., Clennell, M.B. and Flecker, R., 1998, Mechanism of mud extrusion on the Mediterranean Ridge, GeoMarine Letts. 18, 97-114. 
Kreemer, C. and Chamot-Rooke, N., 2004, Contemporary kinematics of the southern Aegean and the Mediterranean Ridge, Geophys. J. Intl. 157, 1377-1392.

Lallemant, S., Truffert, C., Jolivet, L., Henry, P., ChamotRooke, N. and de Voogd, B., 1994, Spatial transition from compression to extension in the Western Mediterranean Ridge accretionary complex, Tectonophysics 234, 33-52.

Le Meur, D., 1997, Étude géophysique de la structure profonde et de la tectonique active de la partie occidentale de la Ride Méditerranéenne. PhD Thesis, Orsay, Paris XI University.

Le Pichon, X., Chamot-Rooke, N., Lallemant, S., Noomen, R. and Veis, G., 1995, Geodetic determination of the kinematics of central Greece with respect to Europe: Implications for Eastern Mediterranean Tectonics, J. Geophys. Res. 100, 12675-12690.

Le Pichon, X., Lallemant, S.J., Chamot-Rooke, N. and Le Meur, D., Pascal, 2002, The Mediterranean Ridge backstop ,and the Hellenic nappes, Marine Geol. 186, 111-125.

Leité, O. and Mascle, J., 1982, Geological structure of the south Cretan continental margin and Hellenic trench, (Eastern Mediterranean), Marine Geol. 49, 199-223.

Limonov, A.F., Woodside, J.M., Cita, M.B. and Ivanov, M.K., 1996, The Mediterranean Ridge and related mud diapirism: a background, Marine Geol. 132, 1-47-19.

Loubrieu, B., Satra, C. and Cagna R., 2001, Morphobathymetric and Backscatter Images of the Eastern Mediterranean Sea and Surroundings. Two sheets, Ifremer-CIESM, special publication, series Maps and Atlas.

Mascle, J., Huguen, C., Benkhelil, J., Chamot-Rooke, N., Chaumillon, E., Foucher, J.P., Griboulard, R., Kopf, A., Lamarche, G., Volkonskaia, A., Woodside, J. and Zitter, T., 1999, Images may show start of European-African plate collision, Eos Trans. Am. Geophys. Union 80, 421, 425, 428.

McClusky, S., Balassanian, S., Barka, A., Demir, C., Ergintav, S., Georgiev, I., Gurkan, O., Hamburger, M., Hurst, K. and Kahle, H., 2000, Global Positioning System constraints on plate kinematics and dynamics in the eastern Mediterranean and Caucasus, J. Geophys. Res. 105, 5695-5719.

Nielsen, C., 2003, Etude des zones de subduction en convergence hyper-oblique: Ride Méditerranéenne - Marge Indo-Birmane. PhD Thesis, Orsay, Paris XI University.
Olivet, J.L., Bonnin, J., Beuzart, P. and Auzende, J.M., 1982, Cinématique des plaques et paléogéographie: une revue, Bull. de la Société Géologique de France XXIV, 875-892.

Reillinger, R.E., McClusty, S.C., Oral, M.B., King, R.W. and Toksoz, M.N., 1997, Global positionning system measurements of present-day crustal movements in the Arabia-Africa-Eurasia plate collision zone, J. Geophys. Res. 102, 9983-9999.

Reston, T.J., Fruehn, J., van Huene, R. and the IMERSE Working Group,, 2002a, The structure and evolution of the Western Mediterranean Ridge, Marine Geol. 186, 83110.

Reston, T.J., von Huene, R., Dickmann, T., Klaeschen, D. and Kopp, H., 2002b, Frontal accretion along the Western Mediterranean Ridge; the effects of Messinian evaporites on wedge mechanics and structural style, Marine Geol. 186, 59-82.

Robertson, A.H.F. and Shipboard Scientific Party, 1996, Mud volcanism on the Mediterranean Ridge: Initial results of Ocean Drilling Program Leg 160. Geology 24, 239-242.

Ryan, W.B.F., Hsü, K.J., (ed.), 1973, Initial Report of the Deep-Sea Drilling Project, Leg XIII, (U.S. Governement Printing Office) Washington.

Tortorici, L., Monaco, C., Tansi, C. and Cocina, O., 1995, recent and active tectonics in the Calabrian arc (Southern Italy), Tectonophysics 243, 37-55.

Truffert, C., 1992, De la compression de la Ride Méditerranéenne à l'extension en mer Egée: Géodynamique de la Méditerranée Orientale. PhD Thesis, Paris VI University.

Truffert, C., Chamot-Rooke, N., Lallemant, S., de Voogd, B., Huchon, P. and Le Pichon, X., 1993, The crust of the Western Mediterranean Ridge from deep seismic data and gravity modelling, Geophys. J. Intl. 114, 360-372.

Volgin, A.V. and Woodside, J.M., 1996, Sidescan sonar images of mud volcanoes from the Mediterranean Ridge: possible causes of variations in backscatter intensity, Marine Geol. 132, 39-53.

Von Huene, R., Reston, T., Kukwski, N., Dehghani, G.A., Weinrebe, W. and the IMERSE working group, 1997, A subducting seamount beneath the Mediterranean Ridge. Tectonophysics 271, 249-261. 